\title{
A Novel Mutation of the $\delta$-Globin Gene in an Asymptomatic 30-Year-Old Female
}

\author{
Chiara Di Bella Francesca Pugliatti Maria Angela La Rosa Simona Cara \\ Anna Paola Capra Luciana Rigoli
}

Department of Human Pathology, University Hospital, University of Messina, Messina, Italy

$\delta$-Thalassemia (OMIM No. 142000) resulting from mutations on the HBD gene usually has no clinical consequences, but it may cause a reduced rate of hemoglobin $\mathrm{A}_{2}$ $\left(\mathrm{HbA}_{2}\right)[1,2]$. Human $\mathrm{HbA}_{2}\left(\alpha_{2} \delta_{2}\right)$, which contains $\delta$-globin, represents a minor fraction of the $\mathrm{Hb}$ found in human adults. In normal individuals, it constitutes between 2.5 and $3.3 \%$ of the total adult $\mathrm{Hb}$ content as measured by high-performance liquid chromatography [3].

Although genetic defects ( $\delta$-thalassemia o $\mathrm{HbA}_{2}$ variants) that decrease $\mathrm{HbA}_{2}$ levels ( $2 \%$ in heterozygote or $\leq 0.6 \%$ in homozygote subjects) do not affect health, they can

Fig. 1. Electropherogram showing the novel $\delta$-globin gene mutation: cd147 T>C. hinder the diagnosis of the $\beta$-thalassemia trait [4]. Values of $\mathrm{HbA}_{2}>3.2 \%$ associated with microcytosis characterize the $\beta$-thalassemia trait [3]. However, the coinheritance of $\beta$-globin and $\delta$-globin gene mutations can decrease $\mathrm{HbA}_{2}$ values to normal or lower levels due to a decreased $\delta$-chain production. As iron deficiency anemia is also characterized by low $\mathrm{HbA}_{2}$ levels, this disease must firstly be ruled out by evaluating iron parameters. Subsequently, a $\delta$-globin mutation screening should be performed, especially in subjects from geographic areas with a high incidence of $\beta$-thalassemia carriers.
Here, we report a novel mutation of the $\delta$-globin gene which was found in an asymptomatic 30-year-old female from Messina (Sicily, Italy) during a routine screening for thalassemia. We performed biochemical and genetic tests after informed consent was provided by the patient. Hematological parameters and serum ferritin were normal. We found low $\mathrm{HbA}_{2}$ levels on high-performance liquid chromatography screening $\left(\mathrm{HbA}_{2} 1.4 \%\right)$. However, as the patient was from a geographic area with a high prevalence of $\beta$-thalassemia, we performed automatic sequencing of the $\beta$-globin gene (ABI 3130 analyzer, Applied Bio-

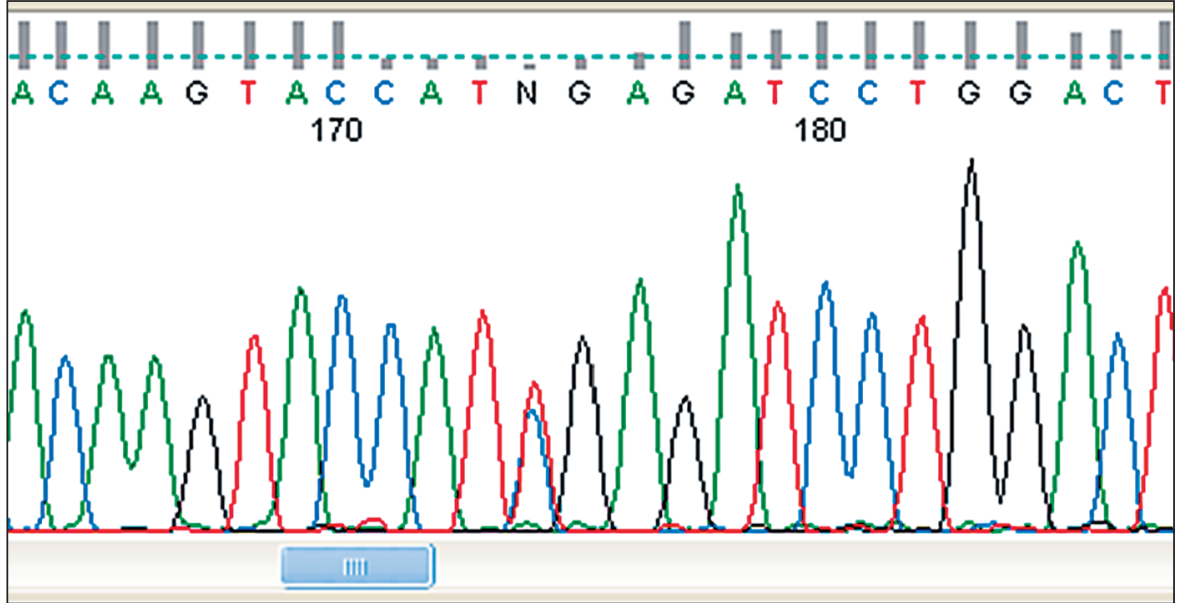

\section{KARGER}

(C) 2018 S. Karger AG, Basel

E-Mail karger@karger.com www.karger.com/aha
Chiara Di Bella

Department of Human Pathology, University Hospital University of Messina, Via Consolare Valeria IT-98125 Messina (Italy)

E-Mail chiara.dibella@ unime.it 
systems, Foster City, CA, USA). DNA extraction was performed according to standard methods. No mutations of the $\beta$-globin gene were found.

Therefore, we amplified DNA samples by polymerase chain reaction to analyze the entire $\delta$-globin gene (promoter region, all exons, and exon-intron junctions) [5]. The amplified samples were subjected to automatic sequencing (ABI 3130 analyzer; Applied Biosystems, Foster City, CA, USA) utilizing the BigDye Terminator Cycle Sequencing kit v3.1 (Applied Biosystems).

We found a novel TGA $>$ CGA (stop to Arg) mutation at cd147 of the $\delta$-globin

\section{References}

1 Jain S, Edison ES, Mathews V, Shaji RV: A novel $\delta$-globin gene mutation (HBD: c. $323 \mathrm{G}>\mathrm{A}$ ) masking the diagnosis of $\beta$-thalassemia: a first report from India. Int J Hematol 2012;95:570-572.

2 Hariharan P, Colaco S, Colah R, Ghosh K, Nadkarni A: Delta globin gene variations leading to reduction in $\mathrm{HbA}_{2}$ levels. Int $\mathrm{J} \mathrm{Lab}$ Hematol 2016;38:610-615. gene in a heterozygous state (Fig. 1). Previously, Alkindi et al. [6] described for the first time a TGA $>$ TTA (stop to Leu) mutation at cd147 in a heterozygous state in a subject who was also homozygous for $-a^{3.7}$ allele. The subject was also asymptomatic and was identified during a screening for $\beta$-thalassemia screening.

Thus, to the best of our knowledge, only 2 mutations have been found in cd147: TGA $>$ CGA (stop to Arg) and TGA $>$ TTA (stop to Leu). Both mutations cause an elongation of 15 amino acids in the protein carboxy terminal. We hypothesize that this elongated $\delta$-globin, similarly to the elon- gated polypeptides $\alpha$-globin and $\beta$-globin, would be unstable [6]. Certainly, the number of mutations on the $\delta$-gene has increased greatly and about $117 \delta$-globin gene mutations have been reported so far (http://globin.cse.psu.edu/hbvar/menu. html) [7].

The presence of HBD mutations could compromise the diagnosis of $\beta$-thalassemia carriers as it produces a lower $\mathrm{HbA}_{2}$. Therefore, the molecular screening of $\delta$-globin gene mutations could be useful for the genetic counseling of at-risk couples from geographic areas in which thalassemia is common.
3 Mosca A, Paleari R, Ivaldi G, Galanello R, Giordano PC: The role of haemoglobin $\mathrm{A}_{2}$ testing in the diagnosis of thalassaemias and related haemoglobinopathies. J Clin Pathol 2009;62:13-17.

4 Giambona A, Passarello C, Ruggeri G, Renda $\mathrm{D}$, Teresi $\mathrm{P}$, Anzà M, Maggio A: Analysis of delta-globin gene alleles in the Sicilian population: identification of five new mutations. Haematologica 2006;91:1681-1684.

5 Bouva MJ, Harteveld CL, van Delft P, Giordano PC: Known and new $\delta$-globin gene mutations and their diagnostic significance. Haematologica 2006;91:129-132.
6 Alkindi S, Alzadjali S, Daar S, Ambusaidi R, Gravell D, Al Haddabi H, Krishnamoorthy R, Pathara A: First report of the spectrum of $\delta$-globin gene mutations in Omani subjects identification of novel mutations. Int J Lab Hematol 2015;37:238-243.

7 Patrinos GP, Giardine B, Riemer C, Miller W, Chui DH, Anagnou NP, Wajcman H, Hardison RC: Improvements in the HbVar database of human hemoglobin variants and talassemia mutations for population and variation studies. Nucleic Acids Res 2004;1:32:D537D541. 